\title{
Sources and Sinks for Atmospheric $\mathrm{N}_{2} \mathrm{O}$
}

\author{
Michael B. McElroy, James W. Elkins, Steven C. Wofsy, and Yuk Ling Yung \\ Center for Earth and Planetary Physics, Harvard University, Cambridge, Massachusetts 02138
}

\begin{abstract}
Observations of the temporal and spatial distribution of $\mathrm{N}_{2} \mathrm{O}$ in solution are not yet sufficient to permit quantitative assessment of the role of the ocean in the budget of atmospheric $\mathrm{N}_{2} \mathrm{O}$. Consideration of the global nitrogen cycle suggests that the land should be the primary source of $\mathrm{N}_{2} \mathrm{O}$. The gas is removed in the atmosphere by photolysis and by reaction with $O\left({ }^{1} D\right)$, and there may be additional sinks in the ocean.
\end{abstract}

\section{INTRODUCTION}

Nitrous oxide plays an important role in the chemistry of atmospheric ozone. The gas is formed as a product of anaerobic decay near the earth's surface. Some fraction of the net planetary source penetrates eventually to the stratosphere, where it can decompose, either by photolysis,

$$
h \nu+\mathrm{N}_{2} \mathrm{O} \rightarrow \mathrm{N}_{2}+\mathrm{O}
$$

or by reaction with $O\left({ }^{1} D\right)$,

$$
\begin{gathered}
\mathrm{O}\left({ }^{1} D\right)+\mathrm{N}_{2} \mathrm{O} \rightarrow 2 \mathrm{NO} \\
\mathrm{O}\left({ }^{1} D\right)+\mathrm{N}_{2} \mathrm{O} \rightarrow \mathrm{N}_{2}+\mathrm{O}_{2}
\end{gathered}
$$

Nitric oxide formed in (2) serves as a catalyst for recombination of $\mathrm{O}_{3}$, mainly [Crutzen, 1970; Johnston, 1971] by

$$
\mathrm{NO}+\mathrm{O}_{3} \rightarrow \mathrm{NO}_{2}+\mathrm{O}_{2}
$$

followed by

$$
\mathrm{NO}_{2}+\mathrm{O} \rightarrow \mathrm{NO}+\mathrm{O}_{2}
$$

We raised earlier [McElroy, 1974, 1976] the possibility that enhanced agricultural productivity, stimulated for the most part by the rapidly growing use of chemical fertilizers, might lead to an increase in the production of $\mathrm{N}_{2} \mathrm{O}$, with consequently serious effects on the equilibrium concentration of atmospheric $\mathrm{O}_{3}$. The possibility of an agriculturally stimulated source of $\mathrm{N}_{2} \mathrm{O}$ was discussed also by Crutzen [1974], who did not, however, offer any quantitative estimate for the magnitude of the resulting decrease in ozone. Crutzen properly recognized the need for a careful study of the global budget of fixed nitrogen. He drew attention to work by Hahn [1974], who concluded that marine sources could play a major role in the global budget for $\mathrm{N}_{2} \mathrm{O}$. Hahn [1974] estimated a source strength for marine $\mathrm{N}_{2} \mathrm{O}$ of magnitude $10^{8}$ metric tons of nitrogen, $\mathrm{N}$, per year, comparable to his result for the total land source.

In our discussion of the nitrogen cycle [McElroy, 1976], we chose not to regard Hahn's data on the North Atlantic as representative of global marine conditions for several reasons. Hahn's data were obtained on cruises that had as their primary goal the study of biological processes in the ocean. As a consequence his data base tended to emphasize regions of high biological productivity, where one might expect relatively large sources of $\mathrm{N}_{2} \mathrm{O}$. All of his measurements were made during the months April-June, a period of intense biological activity. Previous data from the South Pacific [Craig and Gordon, 1963] indicated that at high latitudes, the Pacific appeared to be undersaturated in $\mathrm{N}_{2} \mathrm{O}$ with respect to ambient air. These

Copyright $\odot 1976$ by the American Geophysical Union. data raised the possibility that the ocean might represent a net sink for atmospheric $\mathrm{N}_{2} \mathrm{O}$, rather than a source, a conclusion reached also by Bates and Hays [1967]. Bates and Hays argued that the ocean sink was probably not important in the global budget for $\mathrm{N}_{2} \mathrm{O}$. They thought it probable that the marine sink should be located in the deep ocean, below the thermocline. The data by Junge et al. [1971] and Hahn [1974, 1975], however, suggest that the sink may be active at relatively shallow depths, near the oxygen minimum, and again raise the possibility that the ocean may play an important role in limiting the effective source of atmospheric $\mathrm{N}_{2} \mathrm{O}$.

Hahn's [1974] interpretation of the marine measurements carries certain puzzling implications for the global budget of nitrogen. The difficulties are discussed in more detail below. In brief, an upward flux of $\mathrm{N}_{2} \mathrm{O}$ across the ocean/air interface of magnitude $10^{8}$ tons $\mathrm{yr}^{-1}$ implies a large, as yet unidentified, agent for marine fixation of nitrogen and an exceedingly low efficiency for use of nitrogen by the marine biosphere. On the weight of the evidence, we choose to regard the marine contribution as unknown and use an atmospheric analysis to define the net global source of $\mathrm{N}_{2} \mathrm{O}$, a procedure followed earlier by Bates and Hays [1967].

Variability of atmospheric $\mathrm{N}_{2} \mathrm{O}$ in the lower troposphere suggests a relatively short residence time, of the order of 10-20 yr [Schütz et al., 1970; Junge, 1974; A. Schmeltekopf, personal communication, 1975]. It is difficult to account for a lifetime of this magnitude if reactions (1) and (2) are the only important removal paths for atmospheric $\mathrm{N}_{2} \mathrm{O}$. We suggest here that bacterial consumption of $\mathrm{N}_{2} \mathrm{O}$ in the ocean may represent an additional sink for atmospheric $\mathrm{N}_{2} \mathrm{O}$.

We draw attention also to the possibility that changes in the temperature of surface water may have an influence on the temporal and spatial variability of dissolved oceanic $\mathrm{N}_{2} \mathrm{O}$. An increase in water temperature will cause a decrease in the solubility of $\mathrm{N}_{2} \mathrm{O}$ and will complicate the interpretation of observed supersaturations, especially in regions of rapid mixing, for example, the waters near Iceland.

The role of the ocean is discussed in section 2 . The marine cycle for fixed nitrogen is treated in section 3, and some auxiliary remarks on the fertilizer issue are appended in section 4.

\section{The Role of the Sea}

Hahn's [1974] data on dissolved $\mathrm{N}_{2} \mathrm{O}$ are reproduced in Table 1. Figure 1, taken from Koblentz-Mishke et al. [1970], shows the best available data on the global distribution of primary productivity in the ocean.

Hahn's data were derived from a series of three cruises by the German research vessel Meteor during the Garp Atlantic expedition in 1969 , the Iceland-Faroe Ridge expedition in 
1970, and the North East Atlantic Geosecs (International Geochemical Ocean Sections Program) expedition in 1971. The earlier data by Craig and Gordon [1963] were obtained from the research ship $A$ rgo during a cruise that ranged from the Antarctic circle to San Diego during the period January-April 1961. Craig and Gordon [1963] analyzed a total of 28 samples obtained over a geographic and depth distribution as shown in Figure 2. The origins of the samples used by Hahn [1974] and Craig and Gordon [1963] are shown for convenience in Figure 1.

Hahn [1974] interpreted $\mathrm{N}_{2} \mathrm{O}$ supersaturation as a local phenomenon, in which in situ biogenic production was balanced by a flux through the surface. However, roughly 2 months are required to establish local balance in the top $100 \mathrm{~m}$ of the ocean, a time interval long enough to permit significant variation in the level of biological activity. The water temperature will also vary over this interval. Thus dynamics of ocean surface waters, the time dependence of biological activity, and exchange with the atmosphere may each play a part in regulating the partial pressure of $\mathrm{N}_{2} \mathrm{O}$ in solution.

Consider first the influence of surface water temperature. The solubility of $\mathrm{N}_{2} \mathrm{O}$ decreases by nearly $40 \%$ in response to a temperature increase of $10^{\circ} \mathrm{C}$. It is well-known that variations in surface water temperature can significantly affect the partial pressure of dissolved $\mathrm{CO}_{2}$ and that the solubility of $\mathrm{CO}_{2}$ is similar to that of $\mathrm{N}_{2} \mathrm{O}$. Supersaturation of $\mathrm{CO}_{2}$ is observed primarily in equatorial surface waters, whereas high-latitude waters are characteristically undersaturated, with undersaturations especially prominent at sites that undergo rapid cooling [Keeling, 1968; Keeling and Waterman, 1968].

The data for dissolved $\mathrm{N}_{2} \mathrm{O}$ (Tables 1 and 2) suggest that the concentration of this gas may be similarly affected by changes in water temperature. The largest supersaturations occur in the warmest surface water, at low latitudes. Undersaturation occurs at high latitudes, in cold water [Craig and Gordon, 1963]. Hahn's [1974] high-latitude measurements were taken near Iceland, in relatively warm surface water. His observations were made mostly in June, during the period of maximum solar heating and peak biological activity. Both of these influences might be expected to lead to an increase in the partial pressure of $\mathrm{N}_{2} \mathrm{O}$. Nevertheless, Hahn's [1974] high-latitude samples contained little or no supersaturation.

(Within the uncertainties of measurement and solubility data, saturations of $110 \%$ are not significant. Accurate values for $\mathrm{N}_{2} \mathrm{O}$ solubility in seawater are regrettably unavailable for the temperature range of interest here. It is interesting to note that Junge and Hahn [1971] also considered it possible that the Icelandic data might be explained by physical effects, a view consistent with the arguments developed here.)

The concentration of $\mathrm{N}_{2} \mathrm{O}$ in solution may also be affected by biological sources and sinks. Figure 1 illustrates that the ocean may be quite inhomogeneous from this point of view. More than $41 \%$ of the total ocean surface area may be regarded as unproductive, if we adopt as a working definition the criterion that primary productivity in unproductive regions should correspond to a carbon fixation rate of less than 100 $\mathrm{mg} / \mathrm{m}^{2} /$ day. The Soviet data on primary productivity were derived from a series of over 7000 stations, maintained during a variety of cruises and international expeditions spread over a fairly broad time frame. The North Atlantic on a global scale is relatively productive. The Meteor cruises did not encompass any particularly unproductive regions of the sea, and indeed the high readings (supersaturations in excess of $170 \%$ ) of dissolved $\mathrm{N}_{2} \mathrm{O}$ were obtained from measurements on one cruise at
TABLE I. $\mathrm{N}_{2} \mathrm{O}$ in the Surface Water of the North Atlantic Ocean

\begin{tabular}{|c|c|c|c|c|c|c|}
\hline \multirow{2}{*}{$\begin{array}{c}\text { Sample } \\
\text { No. }\end{array}$} & \multicolumn{2}{|c|}{ Position } & \multirow[b]{2}{*}{ Depth, m } & \multirow{2}{*}{$\begin{array}{c}\text { Conc., } \\
\mu \mathrm{g} / \mathrm{l}\end{array}$} & \multirow{2}{*}{$\begin{array}{c}\text { Temp., } \\
{ }^{\circ} \mathrm{C}\end{array}$} & \multirow{2}{*}{$\begin{array}{c}\% \\
\text { Sat }\end{array}$} \\
\hline & ${ }^{\circ} \mathrm{N}$ & ${ }^{\circ} \mathrm{W}$ & & & & \\
\hline \multicolumn{7}{|c|}{ Expedition 16, April 1969} \\
\hline 1 & 0.6 & 32 & 0 & 0.50 & 27.0 & 232 \\
\hline 2 & 10.3 & 32 & 25 & 0.65 & 21.0 & 293 \\
\hline 3 & 25.6 & 30 & 0 & 0.46 & 22.0 & 175 \\
\hline 4 & 36.6 & 30 & 0 & 0.42 & 17.5 & 145 \\
\hline 5 & 36.6 & 30 & 0 & 0.49 & 17.5 & 169 \\
\hline 6 & 59.9 & 30 & 0 & 0.50 & 5.0 & 119 \\
\hline 7 & 59.9 & 30 & 0 & 0.55 & 5.0 & 131 \\
\hline \multicolumn{7}{|c|}{ Expedition 20b, June 1970} \\
\hline 1 & 62.0 & 12.3 & $0-2$ & 0.40 & 10.3 & 107 \\
\hline 2 & 62.7 & 11.3 & $0-2$ & 0.40 & 9.8 & 106 \\
\hline 3 & 64.1 & 8.5 & $0-2$ & 0.38 & 9.8 & 104 \\
\hline 4 & 62.9 & 11.5 & $0-2$ & 0.40 & 9.5 & 106 \\
\hline 5 & 62.3 & 13.3 & $0-2$ & 0.39 & 9.7 & 104 \\
\hline 6 & 62.0 & 14.7 & $0-2$ & 0.51 & 9.6 & 135 \\
\hline 7 & 63.4 & 15.0 & $0-2$ & 0.40 & 10.4 & 109 \\
\hline 8 & 63.0 & 19.3 & $0-2$ & 0.40 & 10.6 & 109 \\
\hline 9 & 63.3 & 18.1 & $0-2$ & 0.44 & 10.6 & 119 \\
\hline 10 & 63.5 & 14.7 & $0-2$ & 0.43 & 10.7 & 118 \\
\hline 11 & 63.9 & 13.4 & $0-2$ & 0.43 & 10.4 & 115 \\
\hline 12 & 64.9 & 8.2 & $0-2$ & 0.52 & 3.9 & 113 \\
\hline 13 & 64.9 & 8.2 & $20-30$ & 0.49 & 4.8 & 110 \\
\hline 14 & 65.3 & 9.0 & $0-2$ & 0.48 & 5.2 & 108 \\
\hline 15 & 65.1 & 11.1 & $0-2$ & 0.49 & 5.3 & 112 \\
\hline 16 & 65.1 & 11.1 & $0-2$ & 0.51 & 5.3 & 116 \\
\hline 17 & 64.5 & 13.8 & $0-2$ & 0.57 & 3.9 & 123 \\
\hline 18 & 64.2 & 14.0 & $0-2$ & 0.51 & 7.4 & 125 \\
\hline 19 & 65.5 & 11.6 & $0-2$ & 0.48 & 5.3 & 110 \\
\hline 20 & 64.2 & 13.1 & $0-2$ & 0.47 & 7.2 & 115 \\
\hline \multicolumn{7}{|c|}{ Expedition 23c, June 1971} \\
\hline 1 & 38.5 & 11.5 & 0 & 0.41 & 16.0 & 125 \\
\hline 2 & 38.5 & 11.5 & 2 & 0.39 & 16.1 & 117 \\
\hline 3 & 38.5 & 11.5 & 20 & 0.42 & 15.5 & 125 \\
\hline $4^{*}$ & 39.9 & 18.8 & 0 & 0.41 & 19.3 & 126 \\
\hline 5 & 39.9 & 18.8 & 0 & 0.40 & 16.1 & 121 \\
\hline 6 & 39.9 & 18.8 & 2 & 0.39 & 16.1 & 120 \\
\hline 7 & 41.2 & 26.0 & 0 & 0.41 & 15.8 & 124 \\
\hline 8 & 41.2 & 26.0 & 20 & 0.41 & 15.6 & 123 \\
\hline 9 & 42.8 & 34.4 & 0 & 0.38 & 18.3 & 125 \\
\hline 10 & 42.8 & 34.4 & 15 & 0.41 & 17.0 & 128 \\
\hline 11 & 43.8 & 43.0 & 0 & 0.37 & 17.9 & 120 \\
\hline 12 & 43.8 & 43.0 & 25 & 0.37 & 17.6 & 118 \\
\hline 13 & 45.8 & 36.9 & 0 & 0.42 & 16.4 & 130 \\
\hline 14 & 48.5 & 24.8 & 0 & 0.42 & 15.3 & 124 \\
\hline 15 & 48.5 & 24.8 & 15 & 0.43 & 15.0 & 127 \\
\hline
\end{tabular}

Conc. is $\mathrm{N}_{2} \mathrm{O}$ concentration (micrograms of $\mathrm{N}_{2} \mathrm{O}$ per liter of seawater), Temp. is water temperature, and Sat. is $\mathrm{N}_{2} \mathrm{O}$ saturation.

*This sample was taken about $1000 \mathrm{~m}$ off the ship.

only three locations, all of which lay within a relatively productive and unusually warm region (see above). It is perhaps instructive to note that only two of these measurements are 'useful' in the present context. The third (Cruise 16), sample number 2 in Table 1, did not include a measurement at the air/sea interface. The measurements at stations $1-3$ account for more than half of Hahn's [1974] result for the total flux of $\mathrm{N}_{2} \mathrm{O}$ from the North Atlantic. Hahn [1974] assumed a mean value for the concentration of dissolved $\mathrm{N}_{2} \mathrm{O}$ equal to $180 \%$ of saturation, a result that is obviously heavily weighted by the data from stations 1-3. Craig and Gordon's [1963] data were obtained over what may appear as a more representative sample of the ocean volume, if biological productivity can be regarded as a suitable criterion with which to define 'representative.'

Craig and Gordon's [1963] results are summarized in Table 2 


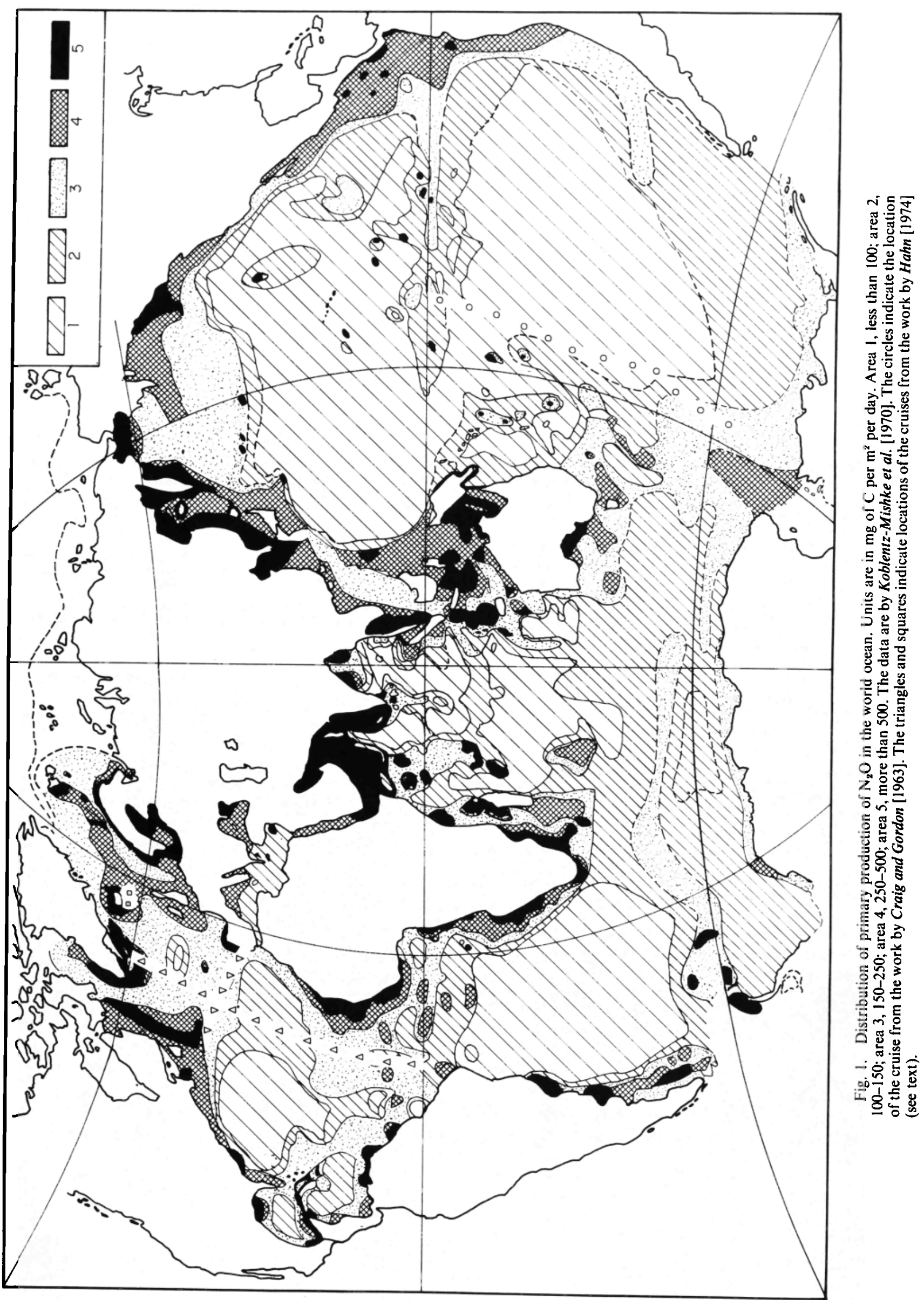




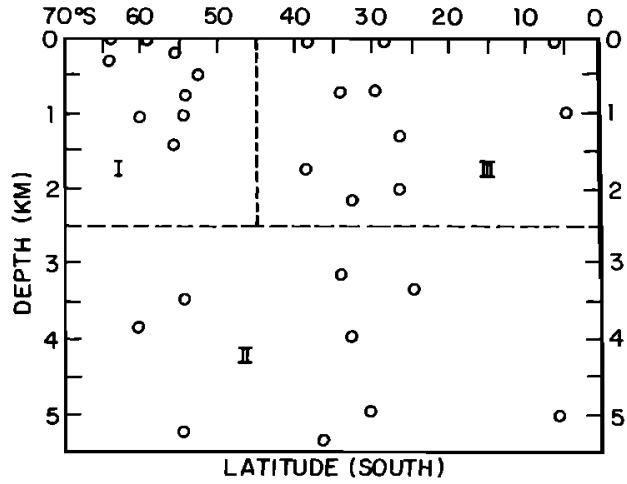

Fig. 2. Location, depth, and group combinations of South Pacific samples analyzed by Craig and Gordon [1963] for $\mathrm{N}_{2} \mathrm{O}$. Station longitudes: at $64.2^{\circ} \mathrm{S}, 166^{\circ} \mathrm{W}$; at $60.2^{\circ} \mathrm{S}, 171.5^{\circ} \mathrm{W}$; at $59.3^{\circ} \mathrm{S}, 169.5^{\circ} \mathrm{W}$; between $20^{\circ}$ and $40^{\circ} \mathrm{S}$, a direct track from $38.5^{\circ} \mathrm{S}, 164^{\circ} \mathrm{W}$, to $24.5^{\circ} \mathrm{S}$, $155^{\circ} \mathrm{W}$; at $4.4^{\circ}$ to $5.7^{\circ} \mathrm{S}, 149.5^{\circ} \mathrm{W}$. Surface samples shown were taken at $10 \mathrm{~m}$.

for the geographic regions I, II, and III denoted in Figure 2. We carried out a similar analysis for Hahn's data, with the groupings determined solely by the latitude at which the sample was taken. The comparison reveals an interesting pattern. Both Hahn [1974] and Craig and Gordon [1963] found that the deep ocean was undersaturated. The mean concentrations were identical in both cases. They agreed also in their results for the upper layers of the biologically productive tropical ocean. In both cases the mean concentration of dissolved $\mathrm{N}_{2} \mathrm{O}$ corresponded to about $130 \%$ of saturation with respect to ambient air. The discrepancy emerges from a comparison of data taken at higher latitude. Hahn [1974] found a small supersaturation with an average value of $117 \%$. In contrast, Craig and Gordon [1963] found that high-latitude waters were undersaturated by about $32 \%$. Inspection of Figure 1 indicates that the discrepancy here may be attributed in part to the variegated biological condition of the waters sampled in the two instances. Further inspection of Figure 1 might suggest that the lower productivity was more prevalent and that the North Atlantic might not be representative. The discrepancy might also be interpreted as a temporal effect. Most of Hahn's [1974] data at high latitudes were taken during June, while the samples analyzed by Craig and Gordon [1963] were taken at a later season.

On the basis of the current marine data the net flux of $\mathrm{N}_{2} \mathrm{O}$ across the air/sea boundary could be either up or down. (The flux of a gas across the ocean-atmosphere interface is calculated by the stagnant film model [Broecker and Peng, 1974] based on extensive radioactive radon data. The flux calculated from this model may be questioned for a biologically active gas like $\mathrm{N}_{2} \mathrm{O}$, especially in view of the presence of a biologically active microlayer $(\sim 100 \mu$ thick $)$ on the ocean surface. It is well-known that this layer includes large concentrations of various bacteria [Liss, 1975; Tsiban and Teplinskaya, 1972].) In the discussion below, we argue that the net flux is most likely down, owing to biogenic consumption of $\mathrm{N}_{2} \mathrm{O}$. A quantitative treatment of the marine cycle is difficult, however, in view of the limited nature of the available data base. Our view that the ocean should act as a net sink for $\mathrm{N}_{2} \mathrm{O}$ is weighted by the following factors: our impression is that the variability in atmospheric $\mathrm{N}_{2} \mathrm{O}$ at midcontinental stations such as Boulder, Colorado (A. Schmeltekopf, personal communication, 1975), should imply a relatively short lifetime for the gas; an examination of the profiles for the gas in solution (see below) appears to show evidence for both sources and sinks in the sea;
TABLE 2a. $\mathrm{N}_{2} \mathrm{O}$ Data from the South Pacific [Craig and Gordon, 1963]

\begin{tabular}{lrrrrrr}
\hline $\begin{array}{c}\text { No. of } \\
\text { Samples }\end{array}$ & $\begin{array}{c}\text { Depth } \\
\text { Range, } m\end{array}$ & $\begin{array}{c}\text { Average } \\
\text { Depth, } m\end{array}$ & $\begin{array}{c}\text { Latitude } \\
\text { Range }\end{array}$ & $\begin{array}{c}\text { Conc., Temp., } \\
\mu \mathrm{g} / 1\end{array}$ & $\begin{array}{c}\% \\
{ }^{\circ} \mathrm{C}\end{array}$ & $\begin{array}{c}\% \\
\text { Sat.* }\end{array}$ \\
\hline $\begin{array}{l}\text { Group I } \\
\mathbf{9}\end{array}$ & $10-1400$ & 600 & $45^{\circ}-70^{\circ} \mathrm{S}$ & 0.36 & 3.5 & 68 \\
$\begin{array}{c}\text { Group II } \\
9\end{array}$ & $3000-5100$ & 4000 & $0^{\circ}-70^{\circ} \mathrm{S}$ & 0.32 & 1.3 & 57 \\
$\begin{array}{l}\text { Group III } \\
10\end{array}$ & $10-2200$ & 900 & $0^{\circ}-44^{\circ} \mathrm{S}$ & 0.53 & 9.7 & 125 \\
\hline
\end{tabular}

Station longitudes: at $64.2^{\circ} \mathrm{S}, 166^{\circ} \mathrm{W}$; at $60.2^{\circ} \mathrm{S}, 171.5^{\circ} \mathrm{W}$; at $59.3^{\circ} \mathrm{S}, 169.5^{\circ} \mathrm{W}$; between $20^{\circ}$ and $40^{\circ} \mathrm{S}$, a direct track from $38.5^{\circ} \mathrm{S}, 164^{\circ} \mathrm{W}$, to $24.5^{\circ} \mathrm{S}, 155^{\circ} \mathrm{W}$; at $4.4^{\circ}$ to $5.7^{\circ} \mathrm{S}, 149.5^{\circ} \mathrm{W}$.

Conc. is $\mathrm{N}_{2} \mathrm{O}$ concentration (micrograms of $\mathrm{N}_{2} \mathrm{O}$ per liter of seawater). Temp. is water temperature, and Sat. is $\mathrm{N}_{2} \mathrm{O}$ saturation.

*The partial pressure of $\mathrm{N}_{2} \mathrm{O}$ in air was $0.285 \mathrm{ppm}$. The solubility data were by Junge et al. [1971].

TABLE $2 b . \quad \mathrm{N}_{2} \mathrm{O}$ Data From the North Atlantic [Junge et al., 1971; Hahn, 1974]

\begin{tabular}{lrrrrr}
\hline $\begin{array}{c}\text { No. of } \\
\text { Samples }\end{array}$ & $\begin{array}{c}\text { Depth } \\
\text { Range, } m\end{array}$ & $\begin{array}{c}\text { Average } \\
\text { Depth, } m\end{array}$ & $\begin{array}{c}\text { Latitude } \\
\text { Range }\end{array}$ & $\begin{array}{c}\text { Conc., } \\
\mu \mathrm{g} / \mathrm{I}\end{array}$ & $\begin{array}{c}\% \\
\text { Sat. }\end{array}$ \\
\hline $\begin{array}{l}\text { Group I } \\
83\end{array}$ & $0-2000$ & 300 & $45^{\circ}-70^{\circ} \mathrm{N}$ & 0.48 & 117 \\
$\begin{array}{l}\text { Group II } \\
6\end{array}$ & $2500-3000$ & 2800 & $0^{\circ}-70^{\circ} \mathrm{N}$ & 0.33 & 68 \\
$\begin{array}{l}\text { Group III } \\
63\end{array}$ & $0-2200$ & 550 & $0^{\circ}-44^{\circ} \mathrm{N}$ & 0.50 & 136 \\
\hline
\end{tabular}

The data by Junge et al. [1971] and Hahn [1974] were averaged according to Craig and Gordon [1963] (see Figure 2).

Conc. is $\mathrm{N}_{2} \mathrm{O}$ concentration (micrograms of $\mathrm{N}_{2} \mathrm{O}$ per liter of seawater), and Sat. is $\mathrm{N}_{2} \mathrm{O}$ saturation.

we are unable to find alternate loss processes that might more plausibly account for the empirical data on lifetime.

The observational data summarized in Tables $I$ and 2 seem to show direct evidence for marine sources and sinks, and the point is illustrated further by several profiles for dissolved $\mathrm{N}_{2} \mathrm{O}$ reproduced from the paper by Junge et al. [1971] in Figure 3. These data show regions that are significantly undersaturated with respect to atmospheric $\mathrm{N}_{2} \mathrm{O}$, as well as regions that are supersaturated. The source regions are located typically near

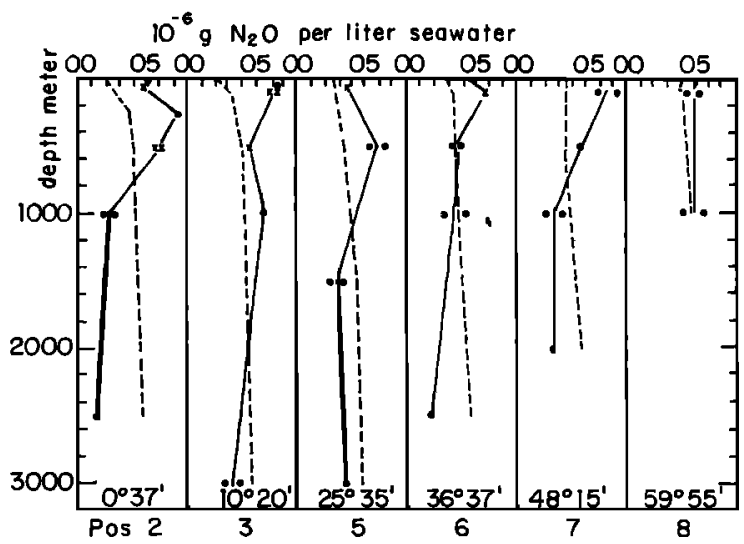

Fig. 3. Vertical profiles of $\mathrm{N}_{2} \mathrm{O}$ in seawater at various positions during the third part of the voyage along $30^{\circ} \mathrm{W}$. If two analyses were made from the same sample, both values are plotted. Crosses are plotted for those samples where some $\mathrm{N}_{2} \mathrm{O}$ losses cannot be excluded; the correct values can be higher as indicated. The dashed lines are the calculated concentrations in equilibrium with the concentration in air of $0.25 \mathrm{ppm}$ according to the water temperature [after Junge et al., 1971]. 
the oxygen minimum [Hahn, 1974], and the sinks would appear also to occur in regions of low oxygen concentration.

A number of bacteria are known to use nitrous oxide as an electron acceptor under anaerobic conditions. In early experiments by Beijerinck and Minkman [1909], the organism Pseudomonas stutzeri was observed to convert a gas containing $85 \% \mathrm{~N}_{2} \mathrm{O}$ to one containing $90 \% \mathrm{~N}_{2}$ in as little as 6 days at $37^{\circ} \mathrm{C}$. Allen and van Niel [1952] found that Pseudomonas had the ability to use either nitrate or nitrous oxide [see also Barbaree and Payne, 1967]. Under conditions where nitrate was abundant, the organisms seemed to favor $\mathrm{NO}_{3}{ }^{-}$as an electron acceptor, with consequent evolution of $\mathrm{N}_{2} \mathrm{O}$. When the supply of nitrate and nitrite was limited, the organisms were observed to switch to $\mathrm{N}_{2} \mathrm{O}$ with subsequent release of $\mathrm{N}_{2}$. Payne et al. [1971] found that the organism Pseudomonas perfectomarinus had the ability to synthesize denitrifying enzymes in 3 hours in the absence of oxygen, and they separated a bacterial population element that could reduce $\mathrm{N}_{2} \mathrm{O}$ but that did not appear able to use either nitrate or nitrite. We may note that the bacterial family discussed here is abundantly present in surface waters of the ocean [Tsiban and Teplinskaya, 1972]. (Respiratory reduction of nitrous oxide in anaerobic conditions represents only one of the possible ways in which the gas may be used by marine bacteria. A variety of microorganisms are known to grow by using nitrogenous oxides as a nitrogen source [Payne, 1973]. Assimilatory reduction may proceed under aerobic conditions and can take place in the surface euphotic layers of the ocean [Hattori and Wada. 1972].)

The sparse observational data preclude a quantitative estimate for the net exchange of $\mathrm{N}_{2} \mathrm{O}$ across the integrated surface areas of the world's oceans. A downward flux of $5 \times 10^{7}$ tons $\mathrm{N}$ per year, which is certainly possible in light of the discussion given here, would imply a lifetime for atmospheric $\mathrm{N}_{2} \mathrm{O}$ of approximately $20 \mathrm{yr}$, a value consistent with the observed variability of surface level $\mathrm{N}_{2} \mathrm{O}$.

In the absence of competing loss processes for $\mathrm{N}_{2} \mathrm{O}$, the atmospheric sinks associated with (1) and (2) consume only $10^{7}$ tons $\mathrm{N}$ per year, and imply therefore a lifetime for atmospheric $\mathrm{N}_{2} \mathrm{O}$ of $118 \mathrm{yr}$. This result was carefully derived from a two-dimensional study of global atmospheric chemistry carried out with procedures described by Wofsy [1976] and with cross sections for (1) measured by Johnston and Selwyn [1975] (see Appendix). The possibility of additional sinks for $\mathrm{N}_{2} \mathrm{O}$ should be studied further, as we seek to develop and refine our understanding of the atmospheric budget for $\mathrm{N}_{2} \mathrm{O}$.

\section{The Nitrogen CyCle}

A model for the global nitrogen cycle, taken from the paper by $M c E l r o y$ [1976], is shown in Figure 4. The discussion here will emphasize transfer processes in the ocean.

McElroy [1976] considered a net source of fixed nitrogen to the world's oceans of magnitude $5 \times 10^{7}$ tons $\mathrm{yr}^{-1}$. This source was supplied in part by rain $\left(2 \times 10^{7}\right.$ tons $)$, in part by river runoff ( $2 \times 10^{7}$ tons), and in part by in situ fixation processes $\left(1 \times 10^{7}\right.$ tons $)$. For a more detailed discussion the reader is referred to the earlier paper, and to the literature cited therein.

The estimate for in situ fixation is by far the most uncertain of the numbers quoted here [see for example Delwiche, 1970]. The organisms most likely to play a role in marine fixation of nitrogen are the blue green algae Trichodesmium and Richelia. Studies of nitrogen fixation in open tropical waters [Dugdale et al., 1961; see also Ryther and Dunstan, 1971] indicate that the process is slow and inefficient. Blue green algae are relatively uncommon, and nitrogen is often the limiting nutrient for algae growth even in the presence of excess phosphate, in contrast to the situation that prevails in most freshwater media

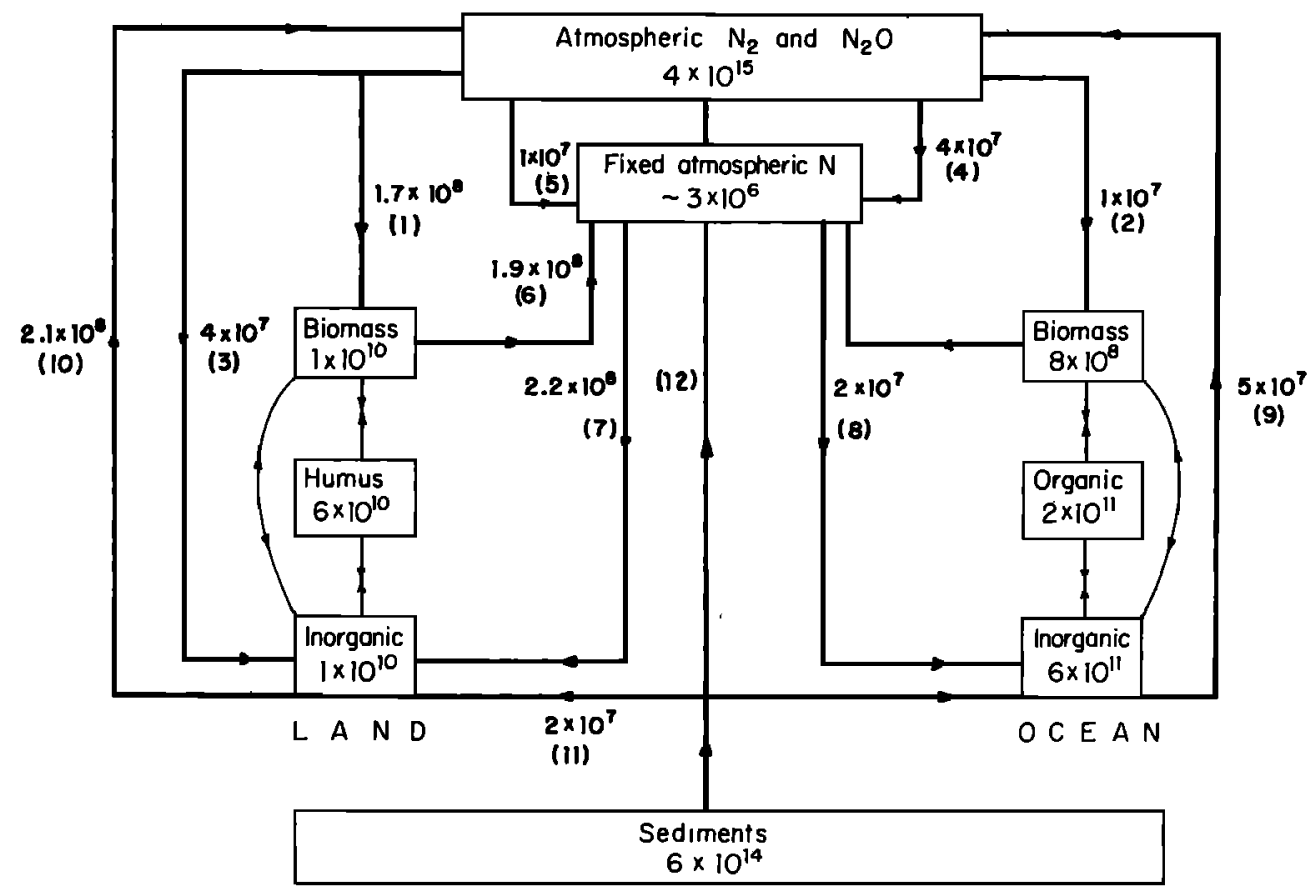

Fig. 4. Representation of the nitrogen cycle. Numbers in rectangular boxes give the abundance of $\mathrm{N}$ measured in metric tons. Transfer rates are given in tons per year, and the numbers in parentheses define the transfer reactions as follows: (1) land biological fixation, (2) marine biological fixation, (3) fixation in chemical fertilizer, (4) fixation due to combustion, (5) fixation due to lightning, (6) transfer due to volatilization of $\mathrm{NH}_{3},(7)$ transfer due to rain over land, (8) transfer due to rain over sea, (9) marine denitrification, (10) land denitrification, (11) transfer from land to sea in river runoff, (12) transfer due to raising of sediments, with a comparable amount due to deposition. 
[Ryther and Dunstan, 1971]. More recent studies of blue green algae in the North Pacific Ocean [Mague et al., 1974] are consistent with this view. It was shown that fixation took place at rather modest rates, during only limited periods, and in isolated locations. These results point strongly to a minor role for in situ fixation, consistent with the view presented by Delwiche [1970]. We shall argue here that the cycle in Figure 4 is at least qualitatively consistent, when it is viewed in a broader context that includes our current understanding of marine productivity.

The bulk of the oceans' fixed nitrogen resides in the deep water below the thermocline. Deep waters exchange with surface layers of the ocean in a period of the order of $10^{3} \mathrm{yr}$, and the upper layers of the ocean acquire a flux of fixed njtrogen, mostly nitrate, of magnitude $6 \times 10^{8}$ tons $\mathrm{yr}^{-1}$ as a consequence of this exchange. Fixed nitrogen is returned to the deep ocean at a rate that must balance the upward flux to a fair degree of accuracy, since sediments are not thought to represent an important sink for N (H. Holland, unpublished manuscript, 1975). The return flux to the deep ocean occurs mainly in organic form as fecal pellets and organic material in various stages of decay.

Consider a net fixation rate for carbon in the marine environment of magnitude $2 \times 10^{10}$, tons $\mathrm{yr}^{-1}$ [Koblentz-Mishke et al., 1970] and a mean value of 12 for the $C / N$ ratio in marine biota [R. Mitchell, private communication, 1975; McElroy, 1976]. These results imply an annual rate for assimilation of $\mathrm{N}$ of magnitude $1.6 \times 10^{9}$ tons $\mathrm{yr}^{-1}$. The demand for $\mathrm{N}$ may be satisfied in part by transport from below $\left(6 \times 10^{8}\right.$ tons $\left.\mathrm{yr}^{-1}\right)$, in part by transfer from land $\left(4 \times 10^{7}\right.$ tons $\left.\mathrm{yr}^{-1}\right)$, and in part by in situ fixation $\left(1 \times 10^{7}\right.$ tons $\left.\mathrm{yr}^{-1}\right)$. The remainder $\left(9.5 \times 10^{8}\right.$ tons $\mathrm{yr}^{-1}$ ) must be supplied by reuse of fixed nitrogen in surface waters. These numbers may be combined to obtain an estimate for the efficiency of the marine nitrogen cycle. Denitrification, which must balance in situ fixation plus supply from the land, accounts for a net $\mathrm{N}$ loss of magnitude $5 \times 10^{7}$ tons $\mathrm{yr}^{-1}$ with the data in Figure 4. This loss may be compared with the amount of nitrogen recycled according to the present analysis, $1.5 \times 10^{9}$ tons $\mathrm{yr}^{-1}$ (the sum of the return flux to the deep ocean plus reuse of $\mathrm{N}$ above the thermocline). The analysis implies therefore an efficiency of $97 \%$ for the use of nitrogen by marine biota, i.e., the average $\mathbf{N}$ atom is reused some 30 times. A similar analysis for the land component of the biosphere, using the data in Figure 4, gives an efficiency of approximately $80 \%$, i.e., a reuse factor of 5 for the average atom. These efficiency factors may be taken as a gross indication of the extent to which decay occurs under aerobic as distinct from anaerobic conditions. Taken at face value the numbers would seem to imply that anaerobic conditions are somewhat more prevalent on land than in the sea, a result which is at least consistent with what one might have expected on intuitive grounds.

A larger rate for marine denitrification than the value assumed here would imply a correspondingly lower rate for the efficiency of the marine nitrogen cycle. There are reasons to suppose [Goering and Dugdale, 1966; Chen et al., 1972] that $\mathrm{N}_{2} \mathrm{O}$ should be a minor product of marine denitrification. If we consider a net denitrification rate of $3 \times 10^{8}$ tons $\mathrm{yr}^{-1}$ to correspond to the large $\mathrm{N}_{2} \mathrm{O}$ emission rate projected by Hahn [1974], then the efficiency factor for marine $N$ should drop to about $77 \%$. In addition, one is forced with this model to invoke a relatively large rate for marine fixation of $N$, of magnitude $2.6 \times 10^{\mathrm{a}}$ tons $\mathrm{yr}^{-1}$ some 26 times larger than Delwiche's [1970] estimate for this parameter. It seems probable that the ratio of
$\mathrm{N}_{2} \mathrm{O}$ to $\mathrm{N}_{2}$ evolved in marine denitrification should be significantly smaller than the value taken here, $50 \%$. The corresponding value for the $\mathrm{N}$ efficiency factor should be reduced accordingly, and we would require an even larger rate for marine fixation of $\mathrm{N}$.

If we adopt a lifetime for atmospheric $\mathrm{N}_{2} \mathrm{O}$ of $20 \mathrm{yr}$ and assume that less productive areas of the sea represent a major sink, we may estimate a downward flux for $\mathrm{N}_{2} \mathrm{O}$ across the air/sea boundary in these regions of magnitude $5.0 \times 10^{7}$ tons $\mathrm{yr}^{-1}$. This flux complements the sink discussed earlier in connection with reactions ( 1 ) and (2), $1 \times 10^{7}$ tons $\mathrm{yr}^{-1}$. A simple scaling procedure using Hahn's [1974] data in combination with the productivity map in Figure 1 suggests an $\mathrm{N}_{2} \mathrm{O}$ source from productive regions of the ocean of magnitude $1 \times 10^{7}$ tons $\mathrm{yr}^{-1}$. These numbers imply a net flux of $\mathrm{N}_{2} \mathrm{O}$ from the land of magnitude $5 \times 10^{7}$ tons $\mathrm{yr}^{-1}$. The ratio for release of $\mathrm{N}_{2} \mathrm{O}$ relative to $\mathrm{N}_{2}$, in land-based denitrification, would approach a value of order $30 \%$ with these assumptions, which may be compared with the value of $4 \%$ derived earlier by MCElroy [1976] for this parameter. The change implied here results primarily from our assumption of a 20-yr lifetime for atmospheric $\mathrm{N}_{2} \mathrm{O}$. With our revised model, the sea receives a net source of $4 \times 10^{7}$ tons $\mathrm{N}$ of $\mathrm{N}_{2} \mathrm{O}$ per year and releases approximately $9 \times 10^{7}$ tons $\mathrm{yr}^{-1}$ of $\mathrm{N}$ as $\mathrm{N}_{2}$ in order to balance the influx of $\mathrm{N}_{2} \mathrm{O}$, in situ fixation, and the supply of fixed nitrogen from the land.

\section{THE IMPACT OF FERTILIZER: SOME FURTHER REMARKS}

It remains difficult to place a precise time scale on the atmospheric perturbations that might occur owing to the increased use of nitrogenous fertilizer. With Hardy and $\mathrm{Ha}$ velka's [1975] estimates for the rates of $\mathrm{N}$ fixation by various agents, it would appear that man's impact on the fixation cycle is already significant, of order $40 \%$ if one includes fixation of $\mathrm{N}_{2}$ in automobiles and stationary power sources. The anthropogenic influence should dominate by the year 2000 , with the use of fertilizer alone accounting for more than the present rate for biological fixation, $1.8 \times 10^{8}$ tons $\mathrm{yr}^{-1}$, according to Hardy and Havelka [1975].

There are indications that the residence time for fixed nitrogen in agricultural soils is relatively short. Nitrate concentrations in streams draining from heavily fertilized farmlands in Illinois and Nebraska show a maximum approximately 1 yr after heavy applications of fertilizer to surrounding farmlands, and the delay can be attributed to a combination of the times required for nitpate to move into the groundwaters and the time for groundwater to move into major surface drajnage systems [Commoner, 1975]. A lifetime of the order of $20 \mathrm{yr}$ for atmospheric $\mathrm{N}_{2} \mathrm{O}$ would imply that the effect on ozone should occur relatively rapidly once the gas is released to the air. One might note that the lifetimes for $\mathrm{CF}_{2} \mathrm{Cl}_{2}$ and $\mathrm{CFCl}_{3}$, other potential threats to ozone, are thought to be of the order of 68 and $45 \mathrm{yr}$, respectively [Wofsy et al., 1975]. Reductions in ozone of the order of $20 \%$ during the first half quarter of the 21 st century, due to current and future use of fertilizer, are not improbable, and the hazard should be studied with great care in light of its evident societal impact.

One should note also the possibility that there might be significant modification to the relative rates for release of $\mathrm{N}_{2} \mathrm{O}$ and $\mathrm{N}_{2}$ due to changes in the acidity of rain. There are indications that rains falling over most of the northeastern portion of the United States have grown noticeably more acidic 


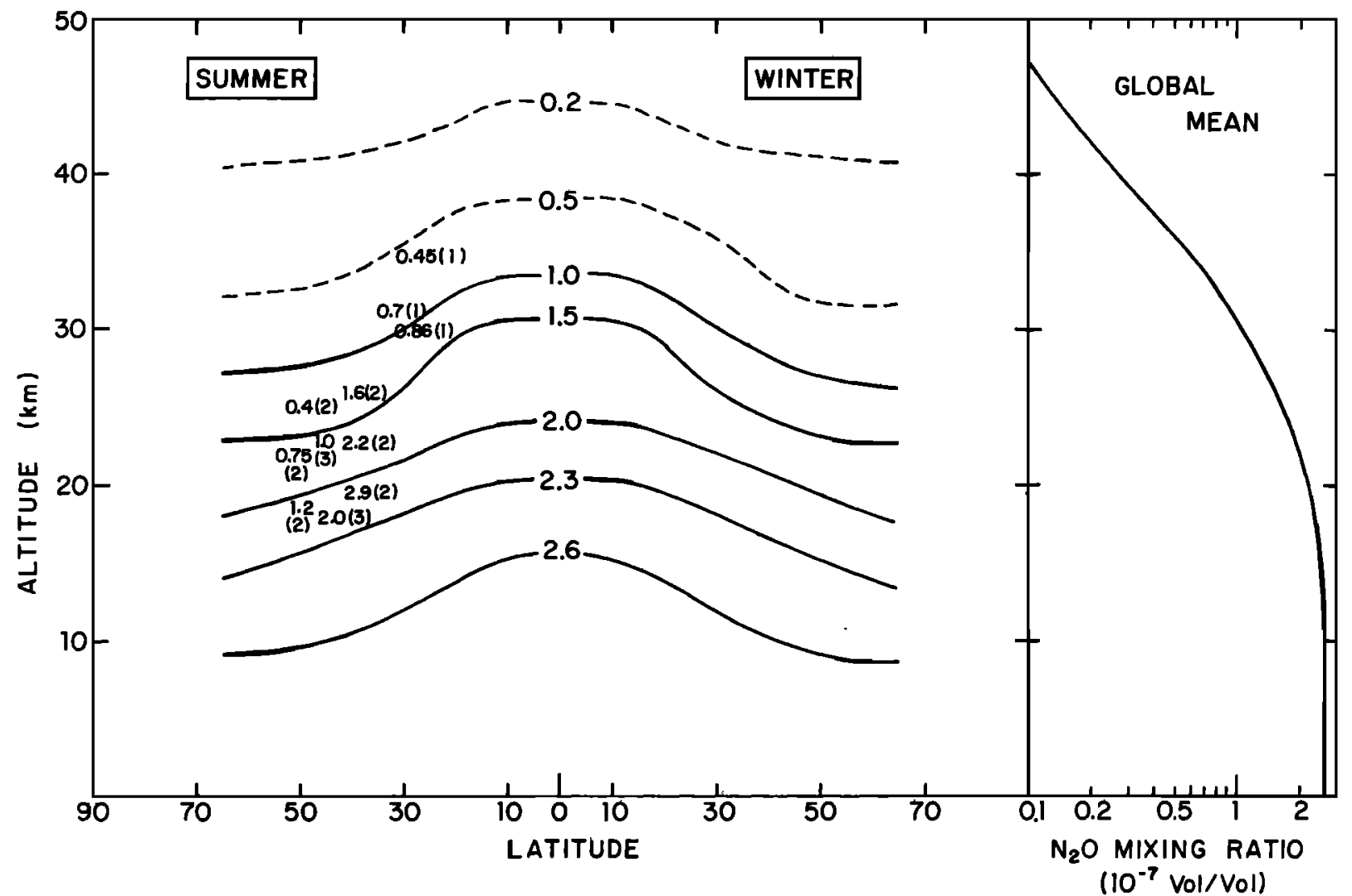

Fig. 5. Distribution of $\mathrm{N}_{2} \mathrm{O}$ (volume mixing ratio times $10^{-7}$ ). (Right panel) Global mean vertical profile from onedimensional 'eddy diffusion' calculation, with parameters as described by Wofsy [1976]. (Left panel) Two-dimensional distribution, derived from the global mean profile as described in the text. The observations are by the following: (1) Ehhalt et al. [1975]; (2) A. Schmeltekopf (personal communication, 1975); (3) Schütz et al. [1970].

over the past $20 \mathrm{yr}$ [Likens and Bormann, 1974] with average values for $p \mathrm{H}$ near 4 , but with values as low as 2.1 recorded for individual storms. A low value for $\mathrm{pH}$ favors the release of $\mathrm{N}_{2} \mathrm{O}$ [Alexander, 1961; Wijler and Delwiche, 1954], if one assumes that other elements of the nitrogen cycle remain unchanged. It is clear though that a change in $p H$ could affect the rate for mineralization of soil nitrogen, and a quantitative assessment of the role of acid rain is difficult, given the major gaps in our current understanding of soil chemistry. The observational evidence reported by Goody [1969] and Schütz et al. [1970] for a rise in the level of atmospheric $\mathrm{N}_{2} \mathrm{O}$ over the 1960 's could reflect in part a change in the relative rate for production of $\mathrm{N}_{2} \mathrm{O}$ during denitrification, in part man's influence on the fixation side of the nitrogen cycle, and in part an increase in the rate for land-based anaerobic decay due to changes in weather. We may note in this context that the major change in $\mathrm{N}_{2} \mathrm{O}$ level seemed to occur during the time interval 1967-1968, a period of unusually cold wet weather in the northern hemisphere [Climatological Data, 1968, 1969].

There is an urgent need for more data to define more accurately the role of the ocean in the global budget for $\mathrm{N}_{2} \mathrm{O}$, to identify the location and nature of possible local sources, to document the temporal variation of global $\mathrm{N}_{2} \mathrm{O}$, and to identify possible additional sinks for the gas in the atmosphere.

\section{APPENDIX: LIFETIME FOR A TMOSPHERIC $\mathrm{N}_{2} \mathrm{O}$}

Figure 5 shows the adopted one- and two-dimensional distributions of $\mathrm{N}_{2} \mathrm{O}$. The one-dimensional eddy transport equation used to obtain a global mean vertical profile for $\mathrm{N}_{2} \mathrm{O}$, using $K_{z}$ from the paper by Wofsy [1976]. The global mean profile was assumed to characterize the atmosphere at $\sim 30^{\circ} \mathrm{N}$, and the two-dimensional distribution was obtained by projecting the $30^{\circ}$ profile along isopleths obtained from ${ }^{14} \mathrm{C}$ and ${ }^{90} \mathrm{Sr}$ observations.

Solar flux data that were taken from the work by Vernazza et al. [1976], agree with the recent observations taken from the Atmospheric Explorer satellite [Hinteregger, 1975]. These fluxes are significantly lower than previous compilations in the critical wavelength range $1900-2100 \AA$. Concentrations of $\mathbf{O}\left({ }^{1} D\right)$ were computed with the full chemical model for the stratosphere [cf. Wofsy, 1976] at various seasons, latitudes, and altitudes.

The results imply a global mean value of $118 \mathrm{yr}$ for the lifetime of atmospheric $\mathrm{N}_{2} \mathrm{O}$ due to reactions (1) and (2) only. The vertical profile at $30^{\circ} \mathrm{N}$ is in excellent agreement with observations up to $34 \mathrm{~km}$ [Ehhalt et al., 1975], and comparison with these data suggests that the computed lifetime should be accurate to $\sim 25 \%$ or better, with the major uncertainty due to possible inaccuracies in solar flux. If we assume a tropospheric mixing ratio of $2.6 \times 10^{-7} \mathrm{vol} / \mathrm{vol}$ for $\mathrm{N}_{2} \mathrm{O}$, the flux into the stratosphere is estimated at $10^{7}$ tons $\mathrm{yr}^{-1}$ of $\mathrm{N}$, of which approximately $3 \%$ is converted to $\mathrm{NO}$ by reaction with $\mathrm{O}\left({ }^{1} D\right)$.

Acknowledgments. It is a pleasure to acknowledge instructive conversations with W.S. Broecker. This research was supported in part by the Atmospheric Research Section, National Science Foundation, and in part by NASA grant NSG 2031 to Harvard University.

\section{REFERENCES}

Alexander, M., Introduction to Soil Microbiology, John Wiley, 472 pp., New York, 1961. 
Allen, M. G., and C. B. van Niel, Experiments on bacterial denitrification, J. Bacteriol., 64, 397, 1952.

Barbaree, J. M., and W. J. Payne, Products of denitrification by a marine bacterium as revealed by gas chromatography, Mar. Biol., l, $136,1967$.

Bates, D. R., and P. B. Hays, Atmospheric nitrous oxide, Planet. Space Sci., 15, 189, 1967.

Beijerinck, M. W., and D. C. J. Minkman, Bildung und Verbrauch von Stickoxydul durch Bakterien. Zentralbl. Bakteriol. Parasitenk. Infektionske. Hyg. Abt. 2, 25, 30, 1909.

Broecker, W. S., and T.-H. Peng, Gas exchange rates between air and sea, Tellus, 26, 21, 1974

Chen, R. L., D. R. Keeney, J. G. Konrad, A. J. Holding, and D. A. Graetz, Gas production in sediments of Lake Mendota, Wisconsin, J. Environ. Qual., 1, 155, 1972.

Climatological Data, National summary, Annual 1967, 18(13), U.S. Dep. of Commer., 1968.

Climatological Data, National summary, Annual 1968, 19(13), U.S. Dep. of Commer., 1969.

Commoner, B., Threats to the integrity of the nitrogen cycle: Nitrogen compounds in soil water, atmosphere and precipitation, in The Changing Global Environment, edited by S. F. Singer, p. 341, D. Reidel, Dordrecht, Netherlands, 1975.

Craig, H., and L. I. Gordon, Nitrous oxide in the ocean and the marine atmosphere, Geochim. Cosmochim. Acta, 27, 949, 1963.

Crutzen, P. J., The influence of nitrogen oxides on the atmospheric ozone content, Quart. J. Roy. Meteorol. Soc., 96, 320, 1970.

Crutzen, P. J., Estimates of possible variations in total ozone due to natural causes and human activities, Ambio, 3, 201, 1974.

Delwiche, C. C., The nitrogen cycle, in The Biosphere, p. 71, W. H. Freeman, San Francisco, 1970.

Dugdale, R. C., D. W. Menzel, and J. H. Ryther, Nitrogen fixation in the Sargasso Sea, Deep Sea Res., 7, 297, 1961.

Ehhalt, D. H., L. E. Heidt, R. H. Lueb, and W. Pollock, The vertical distribution of trace gases in the stratosphere, Pure Appl. Geophys. $113,389,1975$.

Goering, J. J., and V. A. Dugdale, Estimates of the rates of denitrification in a sub-arctic lake, Limnol. Oceanogr., 11, 113, 1966.

Goody, R., Time variations in atmospheric $\mathrm{N}_{2} \mathrm{O}$ in eastern Massachusetts, Planet. Space Sci. 17, 1319, 1969.

Hahn, J., The North Atlantic Ocean as a source of atmospheric $\mathrm{N}_{2} \mathrm{O}$, Tellus, 26, 160, 1974.

Hahn, J., $\mathrm{N}_{2} \mathrm{O}$ measurements in the Northeast Atlantic Ocean, Meteor Forschungsergeb. Reihe A, 16, 1, 1975.

Hardy, R. W. F., and V. P. Havelka, Nitrogen fixation research: A key to world food?, Science, $188,633,1975$.

Hattori, A., and E. Wada, Assimilation of inorganic nitrogen in the euphotic layer of the North Pacific Ocean, in Biology and Oceanography of the Northern North Pacific Ocean, edited by A. Y. Takenout1, p. 279, Idemitsu Shoten, Tokyo, 1972.

Hinteregger, H., paper delivered to the Atmospheric Explorer Team, NASA, Ann Arbor, Mich., September 1975.

Johnston, H. S., Reduction of stratospheric ozone by nitrogen oxide catalysts from SST exhaust, Science, 173, 517, 1971.

Johnston, H. S., and G. Selwyn, New cross sections for the absorption of near ultraviolet radiation by nitrous oxide $\left(\mathrm{N}_{2} \mathrm{O}\right)$, Geophys. Res. Lett., 2, 549, 1975.
Junge, C. E., Residence time and variability of tropospheric trace gases, Tellus, 26, 477, 1974.

Junge, C. E., and J. Hahn, $\mathrm{N}_{2} \mathrm{O}$ measurements in the North Atlantic, J. Geophys. Res., 76, $8143,1971$.

Junge, C. E. B. Bockholt, K. Schütz, and R. Beck, $\mathrm{N}_{2} \mathrm{O}$ measurements in air and sea water over the Atlantic, Meteor Forschungsergeb. Reihe $B, 6,1,1971$.

Keeling, C. D., Carbon dioxide in surface ocean waters, 4, Global distribution, J. Geophys. Res., 73, 4543, 1968.

Keeling, C. D., and L. S. Waterman, Carbon dioxide in surface ocean waters, 3, Measurements on Lusiad expedition 1962-1963, J. Geophys. Res., 73, 4529, 1968.

Koblentz-Mishke, O. J., V. V. Volkovinsky, and J. G. Kobanova, Plankton primary production of the world ocean, in Scientific Exploration of the South Pacific, edited by W. S. Wooster, p. 183, National Academy of Sciences, Washington, D. C., 1970.

Likens, G. E., and F. M. Bormann, Acid rain: A serious regional environmental problem, Science, 184, 1176, 1974.

Liss, P. S., Chemistry of the sea surface microlayer, in Chemical Oceanography, vol. 2, edited by J. P. Riley and G. Skirrow, p. 193, Academic, New York, 1975.

Mague, T. H., N. M. Weare, and O. Holm-Hansen, Nitrogen fixation in the North Pacific Ocean, Mar. Biol., 24, 109, 1974.

McElroy, M. B., Testimony presented to the Committee on Interstate and Foreign Commerce, U.S. House of Representatives, Washington, D. C., Dec. 11, 1974.

McElroy, M. B., Chemical processes in the solar system: A kinetic perspective, in MTP International Review of Science, edited by D. Herschbach, in press, Butterworths, 1976.

Payne, W. J., Reduction of nitrogeneous oxides by microorganisms, Bacteriol. Rev., 37. 409, 1973.

Payne, W. J., P. S. Riley, and C. D. Cox, Jr., Separate nitrite, nitric oxide, and nitrous oxide reducing fractions from Pseudomonas perfectomarinus, J. Bacteriol., 106, 356, 1971.

Ryther, J. H., and W. M. Dunstan, Nitrogen, phosphorus and eutrophication in the coastal marine environment, Science, 17I, 1008, 1971.

Tsiban, A. V., and N. G. Teplinskaya, Microbial population of the Northwestern Pacific waters, in Biology and Oceanography of the Northern North Pacific Ocean, edited by A. Y. Takenouti, p. 541 , Idemitsu Shoten, Tokyo, 1972.

Schütz, K., C. Junge, R. Beck, and B. Albrecht, Studies of atmospheric $\mathrm{N}_{2} \mathrm{O}, J$. Geophys. Res., 75, 2230, 1970.

Vernazza, J. E., E. H. Avrett, and R. Loeser, Structure of the solar chromosphere, 2, The underlying photosphere and temperature minimum region, Astrophys. J., in press, 1976.

Wijler, J., and C. C. Delwiche, Investigations on the denitrifying process in soil, Plant Soil, 5, 155, 1954.

Wofsy, S. C., Interactions of $\mathrm{CH}_{4}$ and $\mathrm{CO}$ in Earth's atmosphere, Annu. Rev. Earth Planet. Sci., 4, in press, 1976.

Wofsy, S. C., M. B. McElroy, and N. D. Sze, Freon consumption: Implications for atmospheric ozone, Science, 187, 535, 1975.

(Received December 8, 1975; accepted December 11, 1975.) 